\title{
Mechanisms promoting and inhibiting the process of proteasomal degradation of cells
}

\author{
Mechanizmy promujące i hamujące proces komórkowej degradacji proteasomalnej
}

\section{Agnieszka Pedrycz ${ }^{1}$ A,B, Agnieszka Kramkowska D,E,F}

\author{
1.Histology and Embryology Department with the Experimental Cytology Laboratory \\ of Medical University of Lublin
}

\begin{abstract}
Defects in the process of degradation of unneeded cellular proteins underlie many diseases. This article discusses one of the most important systems of removal of abnormal proteins. It describes the process of ubiquitination of proteins for proteasome degradation. It also describes the structure of the $26 \mathrm{~S}$ and $20 \mathrm{~S}$ proteasomes and the mechanism of ubiquitin-proteasome system. Proteasome proteolytic system is highly specialized and organized. Protease- proteasome $26 \mathrm{~S}$ is particularly important for proper cell functioning. It recognizes and degrades marked proteins. Inhibition of proteasome pathway leads to cell cycle arrest and apoptosis.

Efficient degradation of cellular proteins by UPS (the ubiquitin - proteasome system) - is important for signal transduction, transcriptional regulation, response to stress and the activity control of cell receptors.

The development of many diseases has its origin in the dysfunction of the UPS route. This group includes diseases such as cancer, neurodegenerative disorders, immune-mediated diseases and infectious diseases. Development of effective methods for pharmacological intervention in the functioning of this system has become a great challenge. The use of specific, low molecular-weight proteasome inhibitors and enzymes catalyzing the ubiquitination gives hope for new, targeted therapies.
\end{abstract}

Keywords: proteasome, lysosome, UPS - ubiquitin-proteasome system

\section{Streszczenie}

Zaburzenia procesu degradacji nieużytecznych komórkowych białek leżą u podstaw wielu chorób. Niniejszy artykuł omawia jeden z najważniejszych systemów usuwających nieprawidłowe białka. Opisany został proces ubikwitynacji białek przeznaczonych do degradacji proteasomalnej. Przedstawiona została budowa proteasomów 26S, 20 S oraz mechanizm działania systemu ubikwitynaproteasom. Proteasomalny system proteolityczny jest systemem wysoce wyspecjalizowanym i zorganizowanym. Dla prawidłowego funkcjonowania komórki istotne znaczenie ma szczególnie proteaza - proteasom 26S. To ona rozpoznaje i degraduje zaznaczone białka. Inhibicja szlaku proteasomów prowadzi do zatrzymania cyklu komórkowego i apoptozy.

Sprawna degradacja białek komórkowych przez szlak UPS (ubikwityna-proteasom) jest istotna dla transdukcji sygnału, regulacji transkrypcji, odpowiedzi na stres oraz kontroli czynności receptorów komórkowych

Rozwój wielu chorób ma swoje podłoże w dysfunkcji szlaku UPS. Zaliczamy do tej grupy takie choroby jak: nowotwory, zaburzenia neurodegeneracyjne, o podłożu immunologicznym i infekcyjnym. Opracowanie metod farmakologicznej interwencji w funkcjonowanie tego układu staje się wielkim wyzwaniem. Zastosowanie swoistych, niskocząsteczkowych inhibitorów proteasomu i enzymów katalizujących ubikwitynację daje nadzieję na nowe, celowane terapie.

Słowa kluczowe: proteasom, lizosom, UPS - system ubiwiktyna-proteasom

\section{Introduction}

The degradation of intracellular proteins is a process that is vital for the proper functioning of a living organism. In the cell, there are two main proteolytic routes: lysosomal and proteasomal. The primary aim of these pathways is the elimination of damaged or misfolded proteins, and those that have already fulfilled their biological function [1].

Proteasomal degradation controls many processes occurring in the cells, among others cell cycle progression, differentiation, intracellular signal transduction, and DNA repair mechanisms. It also oversees the process of programmed cell death $[2,3]$.
In 2004 three researchers: Avram Hershko and Aaron Ciechanover from Israel and Irwin Rose from the United States were awarded the Nobel Prize in chemistry for the discovery of ubiquitin-proteasomal degradation of proteins. They noted that the process is strictly controlled and specific in relation to the substrate protein $[4,5]$.

\section{Proteasomes}

Proteasomes were first isolated in 1980 from the pituitary cells of oxen. They are multisubunit protein complexes characterized by sedimentation constant. Initially they were called multicatalytic proteinase complex (MPC), as within a 
single complex different enzyme activities were observed. The name of the "proteasome" was proposed in 1988 [4].

The $26 \mathrm{~S}$ proteasome (1500 - $2000 \mathrm{kDa}$ ) is composed of the $20 \mathrm{~S}$ core catalytic complex of approximately 700 $\mathrm{kDa}$ (core particle - CP) and a 19S regulatory complex (regulatory particle - RP, activator PA700) [4,6].

The proteasomes are located in the nucleus or cytosol of eukaryotic cells. Their components are named after corresponding Svedberg sedimentation coefficient.

Human proteasome is referred to as 26S. It is capable of hydrolysis of proteins attached to the ubiquitin chains [4]. The center of its ATPase activity is located at the base of the activator complex.

Objaśnienia do rys. 1

\begin{tabular}{|l|l|}
\hline Cząstka regulatorowa 19S & 19S regulatory particle \\
\hline Cząstka rdzeniowa 20S & 20S core particle \\
\hline "pokrywka" & "lid" \\
\hline podstawa & base \\
\hline Aktywność kaspazopodobna & caspase-like activity \\
\hline Aktywność trypsynopodobna & trypsin-like activity \\
\hline Aktywność chymotrypsynopodobna & chymotrypsin-like activity \\
\hline
\end{tabular}
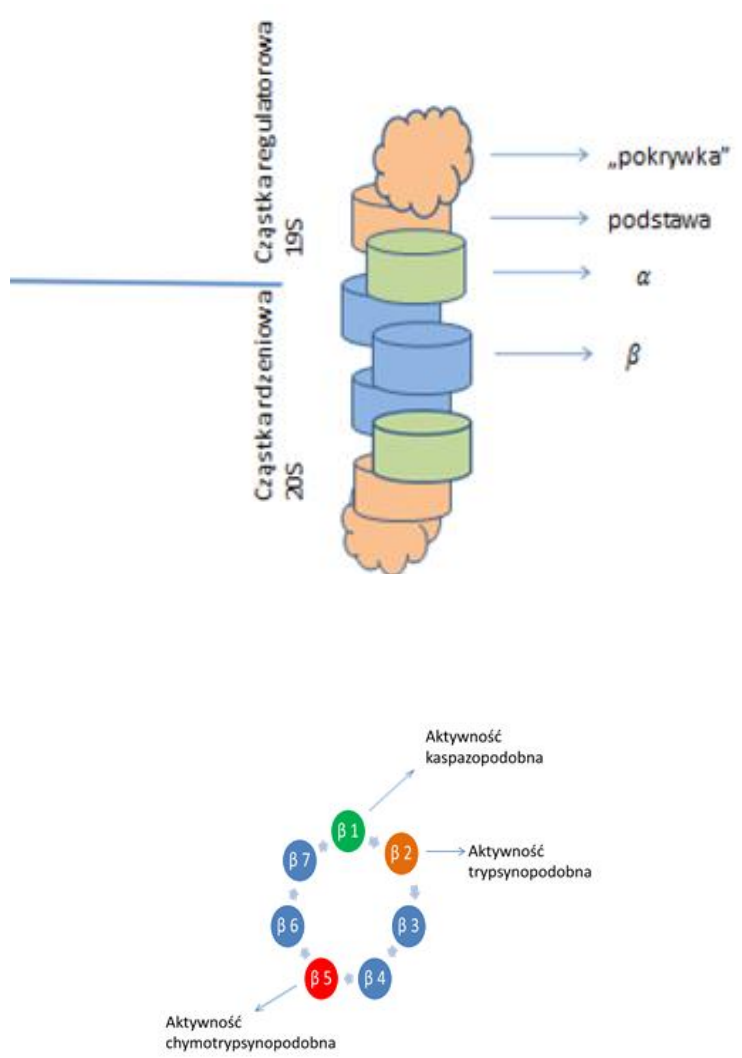

Fig. 1. Composition of the $26 \mathrm{~S}$ proteasome. The complex is composed of the core particle (proteasome 20S) and two regulatory particles 195 . Preoteasome $20 \mathrm{~S}$ consists of two outer rings (each made up of subunits $\alpha 1-\alpha 7$ ) and two inner rings (each made up of subunits $\beta 1-\beta 7$ ). Three of the $\beta$ subunits subtypes is responsible for three basics proteolytic activities of the complex.

The proteasome is a group of interdependent subunits interacting with one another. In yeast $\mathrm{COOH}$-terminal fragment of the $\beta 7$ subunit forming several hydrogen bonds with the $\beta 1$ subunit, stabilizing active centre of the $\beta 1$ subunit is necessary for caspase-like activity. Only the $\beta 5$ subunit of the proteasome can function as a free subunit.

Proteasome 26S or human proteasome is formed by combining the $20 \mathrm{~S}$ proteasome (core) with activator complex PA700 (19S). Ubiquitin-tagged proteins are recognized by the $19 \mathrm{~S}$ regulatory complex, and therefore it plays a dual role - recognizes ubiquitinated proteins and opens the passage to the barrel in the $20 \mathrm{~S}$ proteasome. Such an action requires the energy released from ATP through ATPase with chaperone-like activity. The substrate is unfolded and introduced to the internal compartment of the cylinder. The input channel into the cylinder is guarded by a molecular gate, i.e. N-terminal fragment of a $\alpha 3$ subunit chain. Proteins entering the inner chamber are hydrolyzed in the proteolytic active sites. They are divided into small polypeptides with a length of 3-22 amino acids in the $\beta$ subunits [6]. The proteasome favours branchedchain amino acids (BrAAP - branched-chain amino acids preferring) and low molecular weight neutral amino acids (SNAAP - small neutral amino acid-preferring) [7].

Research has shown that particular activities of a proteasome are associated with different catalytic subunits. Subunits $\beta 1$ are referred to as having C-L activity, subunits $\beta 5$ - CT-L activity, and subunits $\beta 2$ - TL activity (CL - caspase-like activity, CT-L - chymotrypsin-like activity, TL - trypsin-like activity) [8]. Degradation of the substrate occurs during a multicatalytic sequence of events. Studies have shown that the proteasome subunits do not act independently. A hierarchy of proteasome activities and their importance for cell growth has also been determined. It is believed that the most useful activity as a target for therapeutic agents is the chymotrypsin-like activity, followed by the trypsin-like activity, while the least important in this aspect is considered to be the caspase-like activity. This hierarchy was determined on the basis of survival rate of mutants with defects in particular activity [9].

It has also been noted that the relevance of inhibition of particular activities depends largely on the nature of the protein which is degraded. It has also been agreed that simultaneous inhibition of CT-L and L-C activities significantly increases the effect of blocking the proteasome-dependent proteolysis [10].

The active catalytic sites of the proteasome selected in in vitro studies are named according to their substrate specificity. The activity responsible for the disruption of hydrophobic bonds, is called $\beta 5$ chymotrypsin-like activity (CT-L - chymotrypsin-like). As a result of the $\beta 2$ trypsin-like 
activity, - basic amino acid residues are recognized, and bonds at these residues are cleaved (T-L - trypsin-like). Activity $\beta 1$ caspase-like activity results in disconnection of the acid residues of caspases (C-L - caspase-like or PGPH - post-glutamyl peptide hydrolyzing) [8.11].

The core particle is often called the $20 \mathrm{~S}$ proteasome and is not able to perform proteolysis of ubiquitinated proteins. It does not show any ATPase activity either. It is a barrel-like structure composed of four rings. Two of them - the external rings - serve as a "gateway" and consist of $7 \alpha$ subunits each. The two inner rings consist of seven $\beta$ subunits with catalytic activity each. The $\beta 7$ subunit acts as the connection between the $\beta$ rings. In yeast the interaction between the $\mathrm{COOH}$-terminal fragment of this subunit and $\beta 1$ and $\beta 2$ subunits of the opposite $\beta$ ring stabilizes the proteasome. $\mathrm{NH}_{2}$-termini fragments of $\alpha$ subunit chains close the channel leading to the interior cavity of the proteasome ( $\alpha$-gate). The opening of the channel and proteasome activation can be triggered by the connection with the activator or chemically, for example. When treated with SDS (sodium dodecyl sulfate) [4,6,12].

The 19S regulatory particle (activator complex) consists of 19sub-units, 10 of which form a ring adjacent to the core, and the other 9 "a lid" binding a poly-Ub chain (Fig.1). The task of the regulatory particle is to identify a poly-Ub chain and to unfold the protein attached to it so that it can penetrate into the inner chamber of the cylinder, and be subjected to degradation $[13,14,15]$.

The 20S proteasome (core particle), differs from other conventional proteases in that it has the ability of degradation of almost all bonds in the protein substrate, thanks to having multiple peptidase activities inside a single proteolytic chamber [8]. The $20 \mathrm{~S}$ complex is conformationally flexible. The active catalytic sites are located on the inner surface of the cylinder, where they bind to the protein substrates. All $\alpha$ subunit and most of $\beta$ subunits are enzymatically inactive, apart from $\beta 1, \beta 2$ and $\beta 5$ subunits with active centers. They differ among form one another by their sensitivity to inhibitors, and the $\mathrm{pH}$ optimum for their activity.

In the organs of the immune system in response to cytokines released from cells in the early stages of a viral infection (interferon- $\gamma$ INF- $\gamma$ or tumor necrosis factor TNF- $\alpha$ ) are formed specialized forms of proteasome called immunoproteasome (20Si) $[16,17]$. It is build up of alternative catalytic subunits $\beta 1 \mathrm{i}, \beta 2 \mathrm{i}$ and $\beta 5 \mathrm{i}$. Subunits $\beta 2 \mathrm{i}$ and $\beta 5 \mathrm{i}$ are characterised by higher proteolytic activity than their standard counterparts and are used for the production of polypeptides, which subsequently work as the antigens within the MHC I or histocompatibility complex class I [18,13]. A specific type of an immunoproteasome was detected in the thymus and it was termed thymoproteasome. It contains a catalytic unit $\beta 5 \mathrm{t}$ which is characterized by a specific enzymatic activity that is expressed in cortical thymic epithelial cell layer and is involved in positive selection of thymocytes [19].

\section{Ubiquitin}

In the seventies, it was shown that in lysates of reticulocytes there is an ATP-dependent proteolysis of proteins, with a participating thermostable protein at first termed APF-1 (ATP-Dependent Proteolytic Factor 1), which was later found to be identical with discovered several years before ubiquitin [5].

The type of bond which is formed determines the nature of ubiquitination, and the fate of the target protein. Ubiquitin is a 76-amino acid protein with a mass of 8.5 $\mathrm{kDa}$, which is present in all cells and tissues of examined eukaryotes. This protein is characterized by interspecies sequence homology. Ubiquitin of yeast differs from human ubiquitin by only three amino acid residues, is highly thermostable and resistant to a wide range of $\mathrm{pH}$ and polarity of the environment. Monoubiquitination means that one substrate protein was modified with a single residue of ubiquitin, whereas polyubiquitination means that to a substrate protein are attached numerous ubiquitin residues forming straight or branched (multimeric) chains_[4,5,6].

Ubiquitin contains seven lysine residues (K6, K11, $\mathrm{K} 27, \mathrm{~K} 29, \mathrm{~K} 33, \mathrm{~K} 48, \mathrm{~K} 63$ ). It has the form of a monomer or a linear polyubiquitine chain, which is produced by the formation of isopeptide bonds between the carboxyl group of glycine (G76) of one ubiquitin molecule and amino acid residue of lysine of another molecule of this protein. Polyubiquitine chains are formed by joining successive ubiquitin molecules through Lysine 48 residues (K48), so called "classical" chains are the signal for protein degradation. If, however, in the formation of such bondslysine 63 residues (K63) are involved, "non-classical" chains are formed responsible for the regulation of many cellular processes (Fig.2). They take part, among others, in the regulation of the cell cycle, apoptosis, autophagy, DNA repair processes and the immune response [20].

Ubiquitin in a cell plays numerous functions not related to the proteasome pathway, for example it plays a role in regulation of transcription processes, in targeting of proteins from the cell membrane into the ednosomal compartment and movement of proteins from endosomes to multivesicular bodies [4.21]. It also has an indirect effect on the stability of the proteins involved in the regulation of gene expression which occurs within the active euchromatin, which in turn is affected by the state of histones. Histone $2 \mathrm{~A}$ was the first described ubiquitinated protein. It is known that $\mathrm{H} 1$ and H2B histones, are subject to ubiquitination and are present in transcriptionally active regions of chromatin. The structure of histones and their mutual interaction can be modified by the process of ubiquitination and the interaction with DNA. Ubiquitin is- crucial for the formation of "relaxed" chromatin structure, necessary to expose the promoter regions of the genes. It can also facilitate the subsequent histone methylation and influence gene silencing [5.21]. 


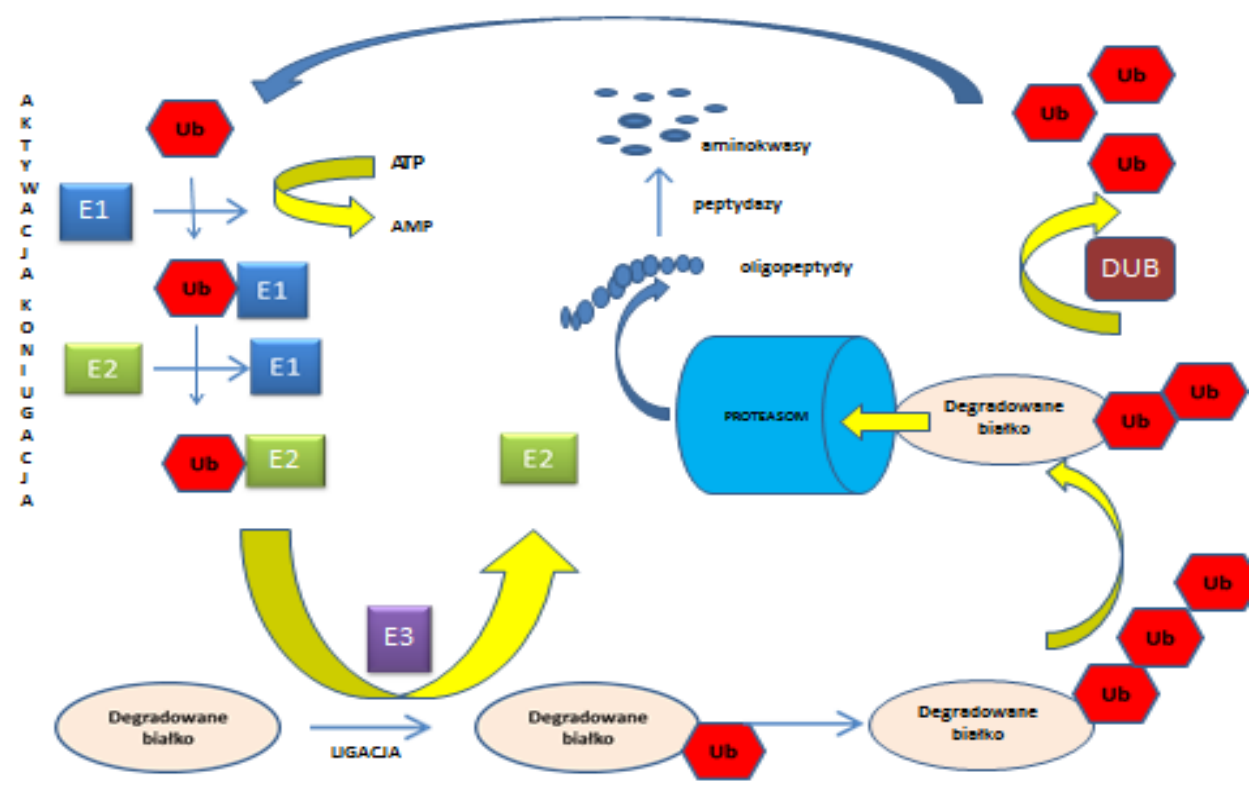

Fig. 2. Mechanism of action of the ubiquitin-proteasome system. Ub - ubiquitin, E1 - ubiquitin-activating enzyme, E2 - ubiquitin-conjugating enzyme, E3 - an enzyme with the ubiquitin-protein ligase activity, DUB - deubiquitinating enzyme

Objaśnienia do rys. 2

\begin{tabular}{|l|l|}
\hline Aktywacja & Activating \\
\hline Koniugacja & Conjugating \\
\hline aminokwasy & amino acids \\
\hline peptydazy & peptidase \\
\hline oligopeptydy & oligopeptides \\
\hline proteasom & proteasome \\
\hline Degenerowane białko & Degenerated protein \\
\hline ligacja & ligation \\
\hline
\end{tabular}

The system referred to as the ubiquitin-proteasome system (UPS), is composed of two elements: the proteasome and ubiquitin. Proteins, which are destined for proteasomal degradation are in the first place recognized and identified by the attachment of ubiquitin (Ub).

\section{Ubiquitination}

Ubiquitination is a post-translational modification of proteins that involves the binding with an isopeptide bond of ubiquitin through a C-terminal glycine residue with the $\varepsilon$ amino group of lysine to the modified protein [22].

Ubiquitination is multi-stage process, with the following stages: (Fig.2)

1. activation of ubiquitin with the E1enzyme,

2. transfer of active ubiquitin on the class E2 enzyme,

3. ligation of ubiquitin with the target protein, catalyzed by the class E3 enzyme.

A ubiquitin molecule attached to the protein destined for- degradation becomes another substrate for the

E3 enzyme. A-s a result of this process, a polyubiquitin (poly-Ub) chain is formed.

A protein with a poly-Ub chain attached, composed of at least four $\mathrm{Ub}$ moieties is recognized by the pro- teasome and after disconnection of the poly-Ub chain by deubiquitinating enzymes (DUB), it is broken down into oligopeptides. The poly-Ub chain is then decomposed into Ub monomers (Fig. 2) [18,13].

Class E1 consists of- a single enzyme but class E2 in mammals consists of about 40 different enzymes. The differences between the enzymes of $\mathrm{E} 2$ are reduced to type of polyubiquitination as Ub molecule contains seven lysine residues, each of which can potentially serve as "the attachment point" for another Ub molecule. E3 class consists of about 1,000 highly specific enzymes whose task is to identify a specific protein and to subject it to polyubiquitination $[18,13]$.

The process of ubiquitination is one of the processes of post-translational modification of proteins. It is characterized by specific steps, in which a protein substrate is recognized and modified. Ubiquitination is irreversible. The modifications that occur in the target proteins refer to specific amino acids (lysine) and change their activity [23]. Ubiquitination signal is recognized and processed by the proteins possessing the ubiquitin-binding domain (UBD). So far, almost 200 proteins characterized by the presence of a single or more domains UBD have been described [20].

The function of the ubiquitin-proteasome system (UPS) is degradation of more than $80 \%$ of intracellular proteins. This system is based on the $26 \mathrm{~S}$ proteasome the dynamic, complex proteolytic subunit with a molecular weight of 1500 to $2000 \mathrm{kD}$, which in eukaryotes is the basis nonlysosomal proteolysis. The function of this intracellular protease is recognition and degradation of the ubiquitin-tagged proteins [2,_24]. 
The ubiquitination process is regulated by the deubiquitinating enzymes (DUB). These enzymes are capable of the hydrolysis of ubiquitin chains produced by the enzymatic cascade E1-E2-E3, both released from the substrates degraded by proteasomes, as well as those attached to undegraded proteins - in this case DUB. They may also protect the substrate from proteasomal hydrolysis and shorten polyubiquitin chains attached to molecules of the substrate [4]. In this manner ubiquitin is directed for a next round of tagging of another protein [22].

\section{Disorders of the ubiquitin-proteasomal pathway}

Efficient degradation of cellular proteins by ubiquitin-proteasome pathway is extremely important for signal transduction, transcriptional regulation, stress response and the control action of receptors.

This pathway controls the activation of nuclear factor NF- $\kappa$ B by degradation of its inhibitor. The proteasome plays a significant role in the antigen presentation. Functional disorders of the UPS destabilize the balance between regulatory proteins, which leads to blocking the cell cycle in G1-S and G2-M phases, and apoptosis [6].

Proteins, which undergo the degradation process by the UPS pathway, have at the N-terminus degron molecules, or specific amino acid sequence with a destabilizing function which include lysine residues with a polyubiquitin chain attached [25]. Precise identification of the protein substrates by ubiquitin enzymes is possible due to numerous post-translational modifications, in particular due to phosphorylation and hydroxylation of specific amino acid residues. Their presence is necessary for- protein recognition by appropriate ligases [25].

The UPS pathway is responsible for degradation of regulatory proteins and tumor suppressors [6].

Deregulation of the UPS pathway is the cause of many diseases. Proteasome dysfunction can have two forms: with a dramatic increase in activity or with a decrease in activity. Diseases associated with loss of normal functioning of the proteasome can be inherited or acquired. Their underlying causes are directly or indirectly linked to disorders in the UPS system. Cancers such as lung, colon, ovary, kidney cancers or myeloblastic leukemia are associated with the increase in the proteasome activity [26]. UPS system disorders are also responsible for neurodegenerative diseases such as Alzheimer's, Parkinson's, Huntington's diseases, prion diseases, as well as spinocerebellar ataxias. In case of HIV and HBV infections, Wilson's disease or Fanconi anemia weakening of the functionality of the UPS pathway is observed [26].

Disorders of the UPS pathway can be responsible for development of cancers and immune-mediated and infectious neurodegenerative diseases. Methods for pharmacological intervention in the operation of this system which include use of specific, small-molecule inhibitors of proteasome and enzymes catalyzing the ubiquitination are the subject of many studies. There are high hopes also in the studies on precise targeting of selected proteins on the proteolysis path with the use of synthetic chimeric adaptor proteins [25.6].

A phenomenon which plays an important role in the neurodegenerative mechanisms is aggregation of misfolded or damaged proteins. Proteins with abnormal spatial structure are built with a large number of $\beta$-type structures with strongly hydrophobic properties. Such a structure of the protein molecule increases its tendency to autoaggregation. Insoluble protein macromolecules are formed in an orderly manner by nucleation. The mechanism triggering nucleation has not yet been discovered. It is known, however, that it starts with formation of the aggregation core composed of protein oligomers, around which the peptide monomers aggregate. In this way at first small filamentary structures, known as protofilaments, are formed, followed by larger structures - filaments. Nucleation and aggregation processes are energy-intensive, unfavorable from the viewpoint of the cell kinetics. They progress very slowly, so the symptoms of some diseases can appears only in patient's middle and old age $[27,28]$.

Recent studies have shown that for the cell degeneration these are not deposits that are responsible, but rather intermediate structural forms that are formed during a gradual process of protein aggregation. It is likely that large protein deposits are inactive or act as cyto-protectors, isolating abnormal proteins and preventing them from interacting with other cell components. Protofilaments and soluble protein oligomers may have neurotoxic effect on the cell. They influence the function of ion channels resulting in increased permeability of cell membranes, as it probably happens in Parkinson's and Huntington's diseases. They also interact with other cell structure and intracellular signaling pathways, which causes disturbances in the flow of information. An example of the latter- disorder is inhibition of the transcriptional activity of the mutant huntingtin. [27,28].

Insufficient performance of ubiquitin-dependent eliminating mechanisms is visible in pathogenesis of neurodegenerative diseases with deposition of protein aggregates. This may lead to the accumulation of pathological proteins, cell dysfunction and its death. It is known that the ubiquitination of the protein and its proteasomal degradation requires energy stored in ATP, which indicates that the deposition of aggregated proteins may be the result of a decrease in ATP synthesis due to a defect in mitochondrial respiratory chain $[29,27]$.

\section{Summary}

Scientific reports, presented in this article show the importance of the mechanisms promoting and inhibiting 
the cellular process of proteasomal degradation. Proper functioning of the UPS pathway maintains the homeostasis of intracellular processes and the removal of damaged proteins. Dysfunction of the UPS pathway underlies many diseases of both the immunological and infectious back- ground. Development of innovative intervention methods based on the use of specific, small-molecule proteasome inhibitors and enzymes catalyzing ubiquitination gives hope for new, targeted therapies.

\section{Wstęp}

Degradacja białek wewnątrzkomórkowych jest procesem, który ma ogromne znaczenie dla prawidłowego funkcjonowania organizmu żywego. W komórce można wyróżnić dwa główne szlaki proteolityczne: lizosomalny i proteasomalny. Celem nadrzędnym tych szlaków jest eliminacja białek uszkodzonych, niepoprawnie sfałdowanych i takich, które wypełniły już swoje funkcje biologiczne [1].

Degradacja proteasomalna kontroluje wiele procesów zachodzących na terenie komórki, m.in. przebieg cyklu komórkowego, różnicowanie, wewnątrzkomórkowe przekazywanie sygnałów, mechanizmy naprawcze DNA. Nadzoruje również proces jej programowanej śmierci [2,3].

W 2004 roku uhonorowano Nagrodą Nobla z dziedziny chemii trzech badaczy: Avrama Hershko i Aarona Ciechanovera z Izraela oraz Irwina Rose z USA za odkrycie ubikwityno-proteasomalnej degradacji białek. Zauważyli oni, że jest to proces ściśle regulowany i swoisty w stosunku do białkowego substratu $[4,5]$.

\section{Proteasomy}

Po raz pierwszy proteasomy wyizolowano w 1980 roku z komórek przysadek mózgowych wołów. Są to złożone kompleksy białkowe o stałej sedymentacji. Początkowo nazwano je wielokatalicznymi kompleksami proteaz MPC (multicatalytic proteinase complex), gdyż w obrębie jednego kompleksu zaobserwowano różne aktywności enzymatyczne. Nazwę „proteasom” zaproponowano w 1988 roku [4].

Proteasom 26S (1500-2000 kDa) składa się z rdzeniowego kompleksu katalitycznego 20S około $700 \mathrm{kDa}$ (core particie - CP) i kompleksu regulatorowego $19 \mathrm{~S}$ (regulatory particie - RP, activator PA700) [4,6].

Proteasomy są zlokalizowane w jądrze komórkowym lub cytosolu komórek eukariotycznych. Ich poszczególne komponenty noszą nazwy związane $\mathrm{z}$ ich stałą sedymentacji Svedberga.

Proteasom człowieka jest określany, jako 26S. Ma on zdolność hydrolizy białek połączonych z łańcuchami ubikwityny [4]. Centrum jego aktywności ATP-azowej znajduje się w podstawie kompleksu aktywatora.

Proteasom jest zgrupowaniem zależnych od siebie podjednostek wzajemnie na siebie oddziałujących. U drożdży $\mathrm{COOH}$-końcowy fragment podjednostki $\beta 7$, tworzący kilka wiązań wodorowych z podjednostką $\beta 1$, poprzez stabilizację centrum aktywnego podjednostki $\beta 1$ jest konieczny dla aktywności kaspazopodobnej. Jedynie podjednostka $\beta 5$ proteasomu może występować, jako wolna [4].
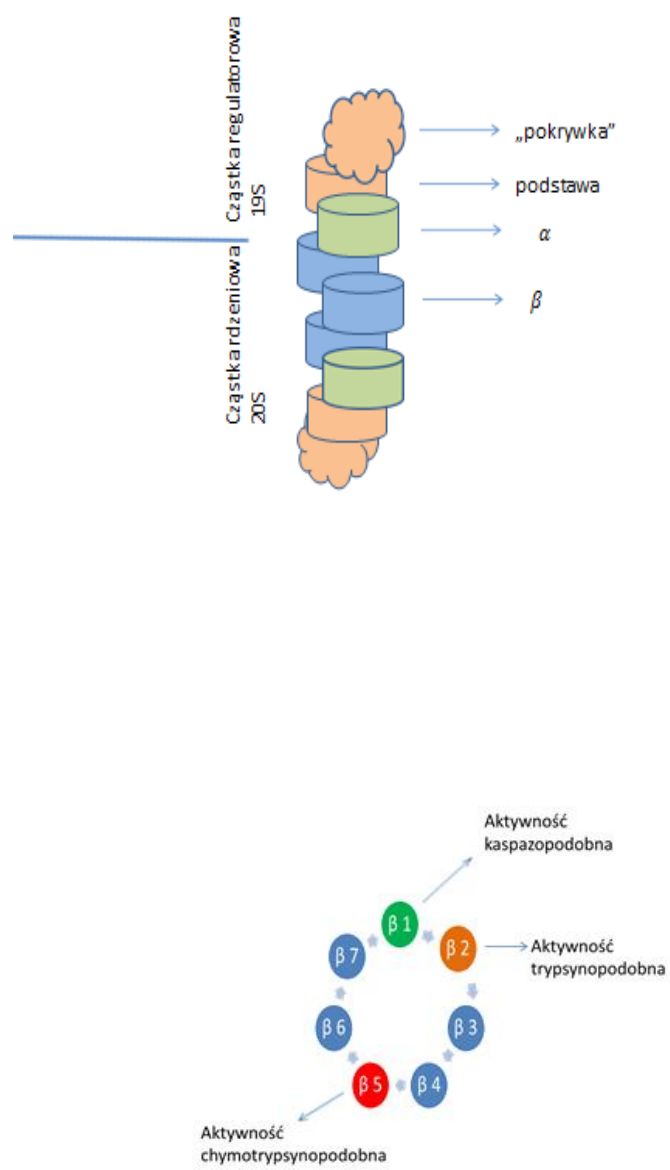

Ryc. 1. Struktura proteasomu 26S. Kompleks składa się z części rdzeniowej (proteasomu 20S) oraz dwóch części regulatorowych 19S. W skład proteasomu 20S wchodzą dwa pierścienie zewnętrzne (każdy złożony z podjednostek $\alpha 1-\alpha 7$ ) oraz dwa pierścienie wewnętrzne (każdy złożony z podjednostek $\beta 1-\beta 7)$. Trzy spośród podtypów podjednostek $\beta$ odpowiadają za trzy podstawowe aktywności proteolityczne kompleksu.

Proteasom 26S, czyli proteasom ludzki, powstaje przez połączenie proteasomu 20S (rdzeń) z kompleksem aktywatora PA700 (19S). Białka znakowane ubikwityną są rozpoznawane przez kompleks regulatorowy 19S, w związku z czym pełni on dwojaką rolę - rozpoznaje ubikwitynowane białko jak również otwiera kanał do cylindra proteasomu 20S. Takie działanie wymaga energii uwalnianej z ATP dzięki ATP-azie o aktywności chaperonopodobnej. Substrat zostaje rozwinięty i wprowadzony 
do wewnętrznych przedziałów cylindra. Kanał wejściowy cylindra jest strzeżony przez bramkę molekularną, tj. $\mathrm{N}$-końcowy fragment łańcucha podjednostki $\alpha 3$. Białka wchodzące do komory wewnętrznej ulegają hydrolizie w aktywnych miejscach proteolitycznych. Są one w podjednostkach $\beta$ dzielone na małe polipeptydy o długości 3-22 aminokwasów [6]. Proteasom preferuje aminokwasy o rozgałęzionych łańcuchach bocznych (BrAAP - branched-chain amino acid-preferring) oraz niskocząsteczkowe aminokwasy neutralne (SNAAP - small neutral amino acid-preferring [7].

Badania udowodniły, iż poszczególne aktywności proteasomu są przyporządkowane różnym podjednostkom katalitycznym. Podjednostki $\beta 1$ są związane z C-L, podjednostki $\beta 5$ podporządkowane CT-L , a podjednostki $\beta 2$ z T-L (C-L - aktywność kaspazopodobna, CT-L - aktywność chymotrypsynopodobna, TL - aktywność trypsynopodobna [8]. Rozpad substratu następuje, jako multikatalityczna sekwencja zdarzeń. Badania wykazały, że podjednostki proteasomu nie działają indywidualnie. Ustalona została również hierarchia aktywności proteasomu oraz jej znaczenie dla wzrostu komórek. Jako najbardziej przydatną, mającą na celu oddziaływanie czynników terapeutycznych uważa się zdolność chymotrypsynopodobną, kolejno trypsynopodobną, natomiast za najmniej ważną uznawana jest kaspazopodobna. Hierarchia ta została ustalona na podstawie przeżywalności mutantów z defektami poszczególnych aktywności [9].

Zauważono również, że istotność hamowania poszczególnych aktywności zależy w dużej mierze od charakteru białka, które w danym przypadku ulega degradacji. Ustalono także, że jednoczesne hamowanie aktywności CT-L oraz C-L znacznie podnosi efekt zablokowania proteolizy zależnej od proteasomu [10].

Aktywne miejsca katalityczne proteasomu wyróżnione podczas badań in vitro mają nazwy zależne od swojej swoistości substratowej. Aktywność odpowiedzialna za rozbijanie wiązań hydrofobowych, nazwana jest aktywnością chymotrypsynopodobną $\beta 5$ (CT-L chymotrypsin-like). W wyniku aktywności trypsynopodobnej $\beta 2$, rozpoznawane są reszty aminokwasów zasadowych i rozcinane wiązania przy tych resztach (T-L trypsin-like). Aktywność kaspazopodobna $\beta 1$ skutkuje odłączaniem reszt kwasowych kaspaz (C-L - caspase-like lub PGPH - post-glutamyl peptide hydrolizing) [8,11].

Rdzeń często nazywany jest proteasomem 20S i nie jest zdolny do proteolizy ubikwitynowanych białek. Nie wykazuje również aktywności ATP-azowej. Ma postać tuby złożonej z czterech pierścieni. Dwa z nich, zewnętrzne, pełnią rolę „bramki” i składają się z 7 podjednostek $\alpha$. Dwa wewnętrzne złożone są z 7 podjednostek $\beta$ o aktywności katalitycznej. Rolę w utrzymaniu połączenia między pierścieniami $\beta$ odgrywa podjednostka $\beta 7$. U drożdży oddziaływanie między COOH-końcowym fragmentem tej podjednostki a podjednostkami $\beta 1$ i $\beta 2$ z przeciwległego pierścienia $\beta$ wpływa na stabilizację proteasomu. NH2-końcowe fragmenty łańcuchów podjednostek $\alpha$ zamykają kanał wiodący do wnętrza proteasomu ( $\alpha$-bramka). Do otwarcia kanału i aktywacji proteasomu może dojść wskutek połączenia $\mathrm{z}$ aktywatorem lub chemicznie, np. pod wpływem SDS (sodium dodecyl sulfate sodowy siarczan dodecylu)[4,6,12].

Cząstka regulatorowa 19S (kompleks aktywatora) składa się z 19 podjednostek, z których 10 tworzy pierścień przylegający do rdzenia, a 9 pozostałych „pokrywkę” wiążącą łańcuch poli-Ub (ryc.1). Zadaniem cząstki regulatorowej jest rozpoznanie łańcucha poli-Ub i rozwinięcie przyłączonego do niego białka, tak aby mogło ono wniknąć do wnętrza rdzenia i tam ulec degradacji [13,14,15].

Proteasom 20S (rdzeń proteasomu), wyróżnia się od innych typowych proteaz tym, że ma zdolność degradacji prawie wszystkich wiązań w substracie białkowym, dzięki posiadaniu kilku aktywności peptydazowych wewnątrz jednej komory proteolitycznej [8]. Kompleks 20S jest konformacyjnie elastyczny. Aktywne miejsca katalityczne umiejscowione są na wewnętrznej powierzchni cylindra, gdzie wiążą się substraty białkowe. Wszystkie podjednostki $\alpha$ i większość $\beta$ są nieaktywne enzymatycznie, oprócz podjednostek $\beta 1, \beta 2$ i $\beta 5$, które mają aktywne centra. Różnią się one między sobą wrażliwością na inhibitory i pH optymalnym dla swej aktywności.

W narządach układu immunologicznego w odpowiedzi na działanie cytokin uwalnianych z komórek we wczesnych stadiach zakażenia wirusowego (INF- $\gamma$ - interferon $\gamma$ bądź TNF- $\alpha$ - czynnik martwicy nowotworu), powstają odpowiedniki proteasomów, zwane immunoproteasomami (20Si) $[16,17]$. Zawierają one alternatywne podjednostki katalityczne $\beta 1 \mathrm{i}, \beta 2 \mathrm{i}$ oraz $\beta 5 \mathrm{i}$. Podjednostki $\beta 2 \mathrm{i}$ oraz $\beta 5 \mathrm{i}$ charakteryzują się większą aktywnością proteolityczną niż ich standardowe odpowiedniki i służą do wytwarzania polipeptydów, które następnie występują, jako antygeny w ramach MHC I czyli układu zgodności tkankowej klasy I, $[18,13]$. Swoisty typ immunoproteasomu wykryto w grasicy i nazwano tymoproteasomem. Zawiera on jednostkę katalityczną $\beta 5 t$, charakteryzującą się specyficzną aktywnością enzymatyczną, która ulega ekspresji w korowej warstwie komórek epitelialnych grasicy i bierze udział w pozytywnej selekcji tymocytów [19].

\section{Ubikwityna}

W latach siedemdziesiątych, wykazano, że w lizatach z retykulocytów zachodzi zależna od ATP proteoliza białek, w której uczestniczy termostabilne białko nazwane początkowo APF-1 (ATP-dependent proteolytic factor 1), które następnie okazało się identyczne z odkrytą kilka lat wcześniej ubikwityną [5]. 


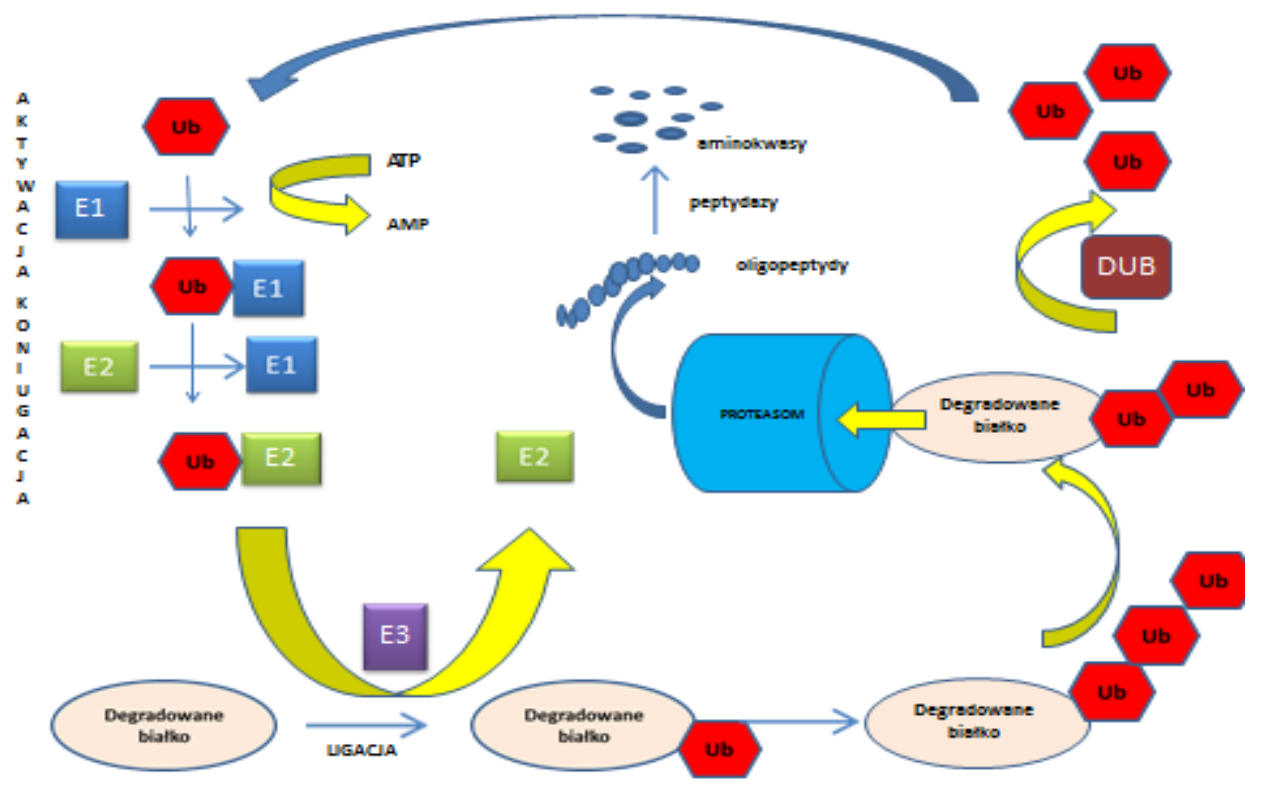

Ryc. 2 Mechanizm działania systemu ubikwityna-proteasom. Ub - ubikwityna, E1 - enzym aktywujący ubikwitynę, E2 - enzym koniugujący ubikwitynę, E3 - enzym o aktywności ligazy ubikwityna-białko, DUB - enzym deubikwitynylujący

Rodzaj tworzonego wiązania decyduje o charakterze ubikwitynacji i dalszych losach białka docelowego. Ubikwityna jest 76-aminokwasowym białkiem o masie 8,5 kDa, występującym we wszystkich zbadanych komórkach i tkankach organizmów eukariotycznych. Białko to ma międzygatunkową homologię sekwencyjną. Ubikwityna drożdży różni się od ludzkiej tylko 3 resztami aminokwasowymi, jest wysoce termostabilna i odporna na szeroki zakres pH oraz polarność środowiska. Monoubikwitynacja oznacza, że białko zmodyfikowano pojedynczą resztą ubikwityny. Poliubikwitynacja zaś oznacza, że dołączone do białka-substratu są liczne reszty ubikwityny, które tworzą łańcuchy proste lub rozgałęzione, inaczej: multimeryczne $[4,5,6]$.

Ubikwityna zawiera siedem reszt lizyny (K6, K11, K27, K29, K33, K48, K63). Występuje w postaci monomeru lub liniowego łańcucha poliubikwitynowego, powstającego przez tworzenie wiązań izopeptydowych między grupą karboksylową glicyny (G76) jednej ubikwityny, a resztą aminową lizyny następnej cząsteczki tego białka. Łańcuchy poliubikwitynowe tworzone przez przyłączanie się kolejnych ubikwityn za pomocą reszty lizyny 48 (K48), tzw. łańcuchy „klasyczne”, są sygnałem do zniszczenia białka. Jeśli jednak w tworzenie takiego wiązania zaangażowane są reszty lizyny 63 (K63), wówczas powstają łańcuchy „nieklasyczne”, biorące udział w regulacji wielu procesów komórkowych (ryc.2). Uczestniczą one m.in. w regulacji cyklu komórkowego, apoptozy, autofagii, procesów naprawczych DNA i odpowiedzi odpornościowej [20]. Ubikwityna pełni w komórce szereg funkcji niezwiązanych ze szlakiem proteasomalnym, np. odgrywa rolę w regulacji procesów transkrypcyjnych, kierowaniu białek z błony komórkowej do kompartmentu endosomalnego oraz przemieszczaniu białek z endosomów do ciałek wielopęcherzykowych $[4,21]$. Ma również pośredni wpływ na stabilność białek biorących udział w procesie regulacji transkrypcji genów, który zachodzi w obrębie aktywnej euchromatyny, na której stan mają wpływ histony. Histon 2A był pierwszym opisanym ubikwitynowanym białkiem. Wiadomo, że histony H2B, H1 podlegają ubikwitynacji i są obecne w aktywnych transkrypcyjnie regionach chromatyny. Struktura histonów i ich wzajemne oddziaływania może zostać zmienione przez proces ubikwitynacji jak również przez oddziaływanie z DNA. Do powstawania „rozluźnionej" struktury chromatyny, koniecznej do odsłonięcia rejonów promotorowych genów jej obecność jest niezbędna. Może także ułatwiać następczą metylację histonów i wpływać na wyciszanie genów [5,21].

System określany, jako ubikwityna-proteasom (UPS), zbudowany jest z dwóch elementów: proteasomu i ubikwityny. Białka, które przeznaczone są do degradacji proteasomalnej w pierwszej kolejności są rozpoznawane i oznaczane przez przyłączenie ubikwityny (Ub).

\section{Ubiwiktynacja}

Ubikwitynacja jest potranslacyjną modyfikacją białek, która polega na połączeniu wiązaniem izopeptydowym ubikwityny poprzez C-końcową resztę glicyny z grupą $\varepsilon$-aminową lizyny białka podlegającego modyfikacji [22].

Proces ubikwitynacji jest kilkuetapowy, przebiega w następujący sposób: (ryc.2)

1. aktywacja ubikwityny przez enzym E1,

2. transfer aktywnej ubikwityny na enzym klasy E2,

3. ligacja ubikwityny z docelowym białkiem, katalizowana przez enzymy klasy E3. 
Cząsteczka ubikwityny przyłączona do białka mającego ulec degradacji staje się następnie kolejnym substratem enzymu E3 w wyniku tego procesu powstaje łańcuch poliubikwityny (poli-Ub).

Białko z przyłączonym łańcuchem poli-Ub, złożonym, z co najmniej 4 reszt $U b$, jest rozpoznawane przez proteasom i po odłączeniu łańcucha poli-Ub przez enzymy deubikwitynylujące (DUB) następuje jego rozkład na oligopeptydy. Łańcuch poli-Ub jest następnie rozkładany na monomery Ub (ryc. 2) [18,13].

Klasa E1 jest to pojedynczy enzym natomiast klasa E2 liczy u ssaków około 40 różnych enzymów. Różnice między enzymami klasy E2 sprowadzają się do typu poliubikwitynylacji, ponieważ cząsteczki Ub zawierają 7 reszt lizynowych, z których każda może potencjalnie służyć, jako „punkt zaczepu” dla następnej cząsteczki Ub. Klasa E3 liczy około 1000 wysoce swoistych enzymów, których zadaniem jest rozpoznanie określonego białka i poddanie go poliubikwitynylacji $[18,13]$.

Proces ubikwitynacji jest jednym z procesów modyfikacji białek potranslacyjnej. Charakteryzuje się stałymi etapami, w których rozpoznawany i modyfikowany jest substrat białkowy. Ubikwitynacja jest nieodwracalna. Modyfikacje, jakie zachodzą w białkach docelowych, dotyczą ściśle określonych aminokwasów (lizyna) i zmieniają ich aktywność [23]. Sygnał ubikwitynacji jest rozpoznawany i przetwarzany przez białka, które mają domenę wiążącą ubikwitynę (ubiquitin-binding domain, UBD). Dotąd udało się opisać prawie 200 białek charakteryzujących się obecnością pojedynczej lub też większej liczby domen UBD [20].

Zadaniem systemu ubikwityna-proteasom (ubiquitin-proteasome system, UPS), jest degradacja ponad 80\% białek wewnątrzkomórkowych. System ten oparty jest na proteasomie 26S - dynamicznym, podjednostkowym kompleksie proteolitycznym, o masie cząsteczkowej 1500-2000 kD, który u organizmów eukariotycznych stanowi podstawę nielizosomalnej proteolizy. Zadaniem tej wewnątrzkomórkowej proteazy jest rozpoznanie i degradacja białek znakowanych przez ubikwitynę [2,24].

Proces ubikwitynacji jest regulowany przez enzymy deubikwitynylujące (DUB). Enzymy te mają zdolność hydrolizy łańcuchów ubikwityny tworzonych przez kaskadę enzymatyczną E1-E2-E3 zarówno uwolnionych z substratów rozłożonych przez proteasomy, jak również związanych z niezdegradowanymi białkami - w tym przypadku DUB. Mogą też chronić substrat przed hydrolizą proteasomalną oraz skracać łańcuchy poliubikwitynowe połączone $\mathrm{z}$ cząsteczkami substratu [4]. Ubikwityna kierowana jest w ten sposób do wtórnego obiegu znakowania następnego białka [22].

\section{Zaburzenia szlaku ubikwityno-proteasomalnego}

Dla transdukcji sygnału, regulacji transkrypcji, odpowiedzi na stres oraz kontroli czynności receptorów niezmiernie istotna jest sprawna degradacja białek komórkowych przez szlak ubikwityna-proteasom.

Szlak ten kontroluje aktywację czynnika jądrowego NF-кB przez degradację jego inhibitora. Prezentacja antygenu odbywa się ze znaczącym udziałem proteasomu. Zaburzenia funkcjonalne układu UPS naruszają równowagę między białkami regulatorowymi, co przyczynia się do zablokowania cyklu komórkowego w fazie G1-S i G2-M oraz apoptozy [6].

Białka ulegające procesowi degradacji na szlaku UPS mają na N-końcu cząsteczki degronów, czyli określonych sekwencji aminokwasowych pełniących funkcje destabilizujące oraz zawierających reszty lizynowe, do których jest dołączany łańcuch poliubikwitynowy [25]. Precyzyjne rozpoznawanie białkowych substratów przez enzymy ubikwitynowe jest możliwe dzięki licznym modyfikacjom potranslacyjnym w szczególności fosforylacji i hydroksylacji określonych reszt aminokwasowych. Ich obecność jest konieczna do rozpoznawania białek przez odpowiednie ligazy [25].

Przez szlak UPS degradacji ulegają białka regulatorowe oraz supresory nowotworowe [6].

Deregulacja układu UPS jest przyczyną wielu schorzeń. Dysfunkcja proteasomu może mieć dwie postacie: następuje drastyczny wzrost aktywności lub jej zmniejszenie. Choroby związane z utratą prawidłowego funkcjonowania proteasomu mogą być dziedziczone lub nabyte. Przyczyny ich są związane bezpośrednio lub pośrednio z zaburzeniami w układzie UPS. Ze wzrostem aktywności proteasomu związane są choroby nowotworowe takie jak: rak płuc, okrężnicy, jajnika, nerki, czy białaczka mieloblastyczna [26]. Zaburzenia układu UPS leżą również u podstaw chorób neurodegeneracyjnych takich jak: choroba Alzheimera, Parkinsona, Huntingtona, prionowe, a także ataksje rdzeniowo-móżdżkowe. W zakażeniach wirusami HIV, HBV, chorobie Wilsona, anemii Fanconiego obserwuje się osłabienie funkcjonalności szlaku UPS [26].

W wyniku zaburzeń szlaku UPS możliwy jest rozwój nowotworów i chorób neurodegeneracyjnych, o podłożu immunologicznym i infekcyjnym. Metody farmakologicznej interwencji $\mathrm{w}$ funkcjonowanie tego układu polegające na zastosowaniu swoistych, niskocząsteczkowych inhibitorów proteasomu i enzymów katalizujących ubikwitynację są przedmiotem wielu badań. Wielkie nadzieje pokłada się również w badaniach nad precyzyjnym kierowaniem wybranych białek na drogę proteolizy z użyciem syntetycznych chimerycznych białek adaptorowych $[25,6]$.

Istotnym zjawiskiem odgrywającym rolę $\mathrm{w}$ mechanizmach neurodegeneracyjnych jest agregacja nieprawidłowo pofałdowanych lub uszkodzonych białek. Białka o nieprawidłowej strukturze przestrzennej mają w swojej budowie dużą liczbę struktur typu $\beta$ o silnie hydrofobowych właściwościach. Taka budowa cząsteczki białka 
zwiększa jego tendencję do autoagregacji. Powstanie nierozpuszczalnych makromolekuł białkowych przebiega w sposób uporządkowany w wyniku zarodkowania (nukleacji). Czynnik wyzwalający zarodkowanie nie został jeszcze poznany. Wiadomo natomiast, że rozpoczyna się ono od wytworzenia jądra agregacji zbudowanego z oligomerów białkowych, wokół którego agregują monomery peptydowe. W ten sposób tworzą się początkowo małe struktury włókienkowe, tzw. protowłókienka (protofilamenty), a potem większe filamenty. Zarodkowanie i agregacja są procesami energochłonnymi, niekorzystnymi z punktu widzenia kinetyki komórki. Zachodzą one bardzo powoli, dlatego pojawienie się objawów niektórych chorób następuje dopiero w średnim i starszym wieku $[27,28]$.

Ostatnie badania wykazują, że za zwyrodnienie komórek nie są odpowiedzialne złogi, ale pośrednie formy strukturalne, które powstają podczas stopniowo przebiegającego procesu agregacji białek. Istnieje prawdopodobieństwo, że duże złogi białkowe są nieaktywne lub odgrywają rolę cytoprotekcyjną, zapobiegając poprzez izolację nieprawidłowych białek ich interakcji z innymi składnikami komórki. Neurotoksyczny wpływ na komórkę mogą wywierać protowłókienka i rozpuszczalne oligomery białkowe. Mają one wpływ na funkcje kanałów jonowych powodując wzrost przepuszczalności błon komórkowych, jak to prawdopodobnie się dzieje w chorobie Parkinsona i Huntingtona. Oddziaływają także na inne struktury komórki i wewnątrzkomórkowe szlaki sygnałowe, co powoduje zaburzenia w przepływie informacji. Przykładem tego ostatniego zaburzenia jest zahamowanie aktywności transkrypcji przez zmutowaną huntingtynę. [27,28].

Niewystarczająca wydajność ubikwityno-zależnych mechanizmów eliminujących jest widoczna w patogenezie chorób neurodegeneracyjnych, w których stwierdza się odkładanie agregatów białkowych. Może prowadzić do akumulacji patologicznych białek, dysfunkcji komórki, a następnie jej śmierci. Wiadomo, że do ubikwitynacji białka, jak i do jego degradacji w proteasomach, potrzebna jest energia magazynowana w ATP, co daje możliwość, że odkładanie się agregatów białkowych może być spowodowane spadkiem syntezy ATP na skutek defektu mitochondrialnych łańcuchów oddechowych [29,27].

\section{Podsumowanie}

Doniesienia naukowe, przedstawione w niniejszym artykule, pokazują, jak wielkie znaczenie mają mechanizmy promujące i hamujące proces komórkowej degradacji proteasomalnej. Prawidłowe funkcjonowanie szlaku UPS umożliwia zachowanie homeostazy procesów wewnątrzkomórkowych i usunięcie uszkodzonych białek. Dysfunkcja szlaku UPS jest przyczyną wielu chorób o różnym podłożu, zarówno immunologicznym, jak i infekcyjnym. Opracowanie innowacyjnych metod interwencji opartych na zastosowaniu swoistych, niskocząsteczkowych inhibitorów proteasomu i enzymów katalizujących ubikwitynację daje nadzieje na nowe, celowane terapie.

\section{Conflict of interest}

The authors have declared no conflict of interest.

\section{References:}

1. Borissenko L., Groll M.: 20S proteasome and its inhibitors: crystallographic knowledge for drug development. Chem Rev. 2007; 107:687-717.

2. O'Neill L.A., Bryant C.E., Doyle S.L.: Therapeutic targeting of Tolllike receptors for infectious and inflammatory diseases and cancer. Pharmacol. Rev., 2009; 61: 177-197.

3. Tsou W.L., Sheedlo M.J., Morrow M.E., Blount J.R., McGregor K.M., Das C., Todi S.V.: Systematic analysis of the physiological importance of deubiquitinating enzymes. PLoS One, 2012; 7: e43112.

4. Bury M., Niemierko A.: Proteasomalna degradacja białek komórkowych. Postępy Biol. Kom., 2005; 32: 435-448.

5. Grzelakowska-Sztabert B.: Nagroda Nobla z chemii za 2004 rok docenienie kontrolowanej, zależnej od ubikwityny, proteolitycznej degradacji białek. Postępy Biol. Kom., 2005; 32: 3-12.

6. Jurczyszyn A., Skotnicki A.B.: Proteasome inhibition as a novel therapeutic target in neoplasmatic diseases. Adv. Clin. Exp. Med., 2006; 15: 309-320.

7. Rechsteiner M., Realini C., Ustrell V:: The proteasome activator 11 S REG (PA28) and class I antigen presentation. Biochem. J., 2000; 345: 1-15.

8. Myung J., Kim K.B., Crews C.M.: The ubiquitin-proteasome pathway and proteasome inhibitors. Med. Res. Rev., 2001; 21: 245-273.

9. Wolf D.H., Hilt W.: The proteasome: a proteolytic nanomachine of cell regulation and waste disposal. Biochim. Biophys. Acta, 2004; 1695: 19-31.

10. Kisselev A.F., Callard A., Goldberg A.L.: Importance of the different proteolytic sites of the proteasome and the efficacy of inhibitors varies with the protein substrate. J. Biol. Chem., 2006; 281: 8582-8590.

11. Richardson P.G., Mitsiades C., Hideshima T., Anderson K.C.: Proteasome inhibition in the treatment of cancer. Cell Cycle, 2005; 4: 290-296.

12. Sprangers R., Kay L.E.: Quantitative dynamics and binding studies of the 20S proteasome by NMR. Nature, 2007; 445: 618-622.)

13. Navon A., Ciechanover A.: The $26 \mathrm{~S}$ proteasome: from basic mechanisms to drug targeting. J. Biol. Chem., 2009; 284: 33713-33718.

14. Sorokin A.V., Kim E.R., Ovchinnikov L.P.: Proteasome system of protein degradation and processing. Biochemistry, 2009; 74: 1411-1442

15. Xie Y.: Structure, assembly and homeostatic regulation of $26 \mathrm{~S}$ proteasome. J. Mol. Cell Biol., 2010; 2: 308-317.

16. Maliński M., Cichocki M.: Inhibicja aktywności proteasomu, jako nowa strategia $\mathrm{w}$ terapii $\mathrm{i}$ chemioprewencji nowotworów. Postępy Hig. Med. Dośw., 2013; 67: 90-106.

17. Miller Z., Ao L., Kim K.B., Lee W.: Inhibitors of the immunoproteasome: current status and future directions. Curr. Pharm. Des.,2013; 19: 4140-4151.

18. Glickman M.H., Ciechanover A.: The ubiquitin-proteasome proteolytic pathway: destruction for the sake of construction. Physiol. Rev., 2002; 82: 373-428.

19. Murata S., Takahama Y., Tanaka K.: Thymoproteasome: probable role in generating positively selecting peptides. Curr. Opin. Immunol., 2008; 20: 192-196.

20. Ikeda F., Crosetto N., Dikic I.: What determines the specificity and outcomes of ubiquitin signaling? Cell, 2010; 143: 677-681. 
21. Mukhopadhyay D., Riezman H.: Proteasome-independent functions of ubiquitin in endocytosis and signaling. Science, 2007; 315: 201-205.

22. Pandey U.B., Nie Z., Batlevi Y., McCray B.A., Ritson G.P., Nedelsky N.B., Schwartz S.L., DiProspero N.A., Knight M.A., Schuldiner O., Padmanabhan R., Hild M., Berry D.L., Garza D., Hubbert C.C., Yao T.P., Baehrecke E.H., Taylor J.P.: HDAC6 rescues neurodegeneration and provides an essential link between autophagy and the UPS. Nature, 2007; 447: 859-863.

23. Martinez-Forero I., Rouzaut A., Palazon A., Dubrot J., Melerol.: Lysine 63 polyubiquitination in immunotherapy and in cancerpromoting inflammation. Clin. Cancer Res., 2009; 15: 6751-6757.

24. Tsou W.L., Sheedlo M.J., Morrow M.E., Blount J.R., McGregor K.M., Das C., Todi S.V.: Systematic analysis of the physiological importance of deubiquitinating enzymes. PLoS One, 2012; 7: e43112.

25. Ciechanover A.: Intracellular protein degradation: from a vague idea thru the lysosome and the ubiquitin-proteasome system and onto human diseases and drug targeting. Hematology, 2006; 1-12: 505-506.

26. Paul S.: Dysfunction of the ubiquitin-proteasome system in multiple disease conditions: therapeutic approaches. Bioessays, 2008; 30: 1172-1184.
27. Dziewulska D., Rafałowska J.: Rola zaburzeń przestrzennej budowy białek $\mathrm{w}$ patomechanizmie chorób układu pozapiramidowego. Neurol. Neurochir. Pol., 2005; 39: 397-404.

28. Nukina N.: Pathomechanism of polyglutamine diseases and strategic design for their therapies. Rinsho Shinkeigaku, 2008; 48: 913-914.

29. Seo H., Sonntag K.C., Kim W., Cattaneo E., Isacson O.: Proteasome activator enhances survival of Huntington's disease neuronal model cells. PLoS One, 2007; 2: e238.

\section{Correspondence address}

Agnieszka Kramkowska

mail:kramkowska@yahoo.com.

tel. 605270629

Otrzymano: 25.01.2016

Zrecenzowano: 08.02.2016, 22.02.2016

Przyjęto do druku: 26.02.2016 